\title{
SYNTHESIS, In-vitro MICROBIOLOGICAL EVALUATION AND MOLECULAR DOCKING OF NOVEL 3,3-DIMETHYL-2,6- DIPHENYL-4-(-2-(2,4,6-TRICHLOROPHENYL) HYDRAZONO)PIPERIDINES
}

\author{
G. Sundararajan ${ }^{1, \bowtie}$, R. Govindharaju ${ }^{1}$ and D. Rajaraman ${ }^{2}$ \\ and K. Krishnasamy ${ }^{3}$ \\ ${ }^{1}$ Thanthai Hans Roever College (Autonomous), Perambalur-621220, (Tamil Nadu) India \\ ${ }^{2}$ St.Joseph University By DMI Sisters and MMI Fathers Dimapur-797115, (Nagaland) India \\ ${ }^{3}$ Department of Chemistry, Annamalai University, Annmalainagar 608 002, India \\ ${ }^{\square}$ Corresponding Author: chemsundar01@gmail.com
}

\begin{abstract}
A series of novel 2,4,6-trichlorophenylhydrazines of 3,3-dimethyl-2,6-diphenyl-4-(-2-(2,4,6trichlorophenyl)hydrazono)piperidines were synthesized and characterized by IR, Mass, ${ }^{1} \mathrm{H} \mathrm{NMR},{ }^{13} \mathrm{C} \mathrm{NMR},{ }^{1} \mathrm{H}-{ }^{1} \mathrm{H}$ COSY and ${ }^{1} \mathrm{H}-{ }^{13} \mathrm{C}$ COSY spectra. Newly synthesized compound Antimicrobial study revealed that compounds (6-9) exhibited excellent in vitro antibacterial activity against $S$. aureus and $B$. subtilis antifungal activity against $C$. albicans, C. tropicalis, A. niger and A. flavus. Molecular docking studies indicated that the synthesized compounds 6-9 possessed appreciable binding energy values against PDB ID: 3LD6 protein. It was more attractive to speculate that the result of the antimicrobial activities varied with the nature of the substituent on the 2,4,6-trichlorophenyl hydrazine at the $\mathrm{C}-4$ position.
\end{abstract}

Keywords:2,4,6-trichlorophenyl hydrazine, IR, 1D-NMR, 2D-NMR Spectroscopy, Molecular Docking, Antimicrobial Activities.

RASĀYAN J. Chem., Vol. 14, No.3, 2021

\section{INTRODUCTION}

Hydrazine derivatives are beneficial compounds. Hydrazines are an important group of heterocyclic compounds due to their drug utility ${ }^{1}$, Hydrazines derivatives very tremendously not only as to modification in structure but also as regard to their therapeutic indication like antitubercular, antimicrobial, antiinflammatory, antiviral and anticanceractivities. ${ }^{2-7}$

Various hydrazine derivatives showed chemotherapeutic properties. ${ }^{8}$ 2,4,6-trichlorophenylhydrazine schiff bases have been reported for theireffective antioxidant activities ${ }^{9}$. Substituted 2,6-diarylpiperidin4-ones ${ }^{10}$ were subjected to quite a large number of synthetic ${ }^{11}$ and physicochemical studies. ${ }^{12-13}$ Due to the importance of the title compound, synthesized and their structure confirmed by spectral studies and biological activities have also been estimated for the synthesized compounds. In addition, piperidine ring is a common structural feature of many alkaloids, natural products and drugs.

In the past decades, there have been many piperidine derivatives ${ }^{14}$ used in clinical and preclinical trials. Piperidin-4-one is an active intermediate in the manufacture of fentanyl analogues ${ }^{15,16}$ which are synthetic primary $\mu$-opioid agonists and potent narcotic analgesics. Besides, multisubstituted piperidines are building units ${ }^{17-19}$ for the synthesis of human GABA-A receptor agonists, farnesyl protein transferase inhibitors and optically active indole alkaloids. The blocking of $\alpha$-positions concerning the nitrogen atom in the piperidine ring by alkyl groups would improve the biological activity. ${ }^{20-23}$ Several3-substituted-2,6diarylpiperidin-4-ones have been evaluated for their antimicrobial efficiency by several researchers.

\section{General Characterization Techniques}

\section{EXPERIMENTAL}

TLC was carried out to monitor the course of the reaction and the purity of the products. Melting points were recorded in open capillaries and were uncorrected. IR spectra were recorded on AVATAR 330 FT- 
RASĀYAN J. Chem.

Vol. 14 | No. 3 |1659-1668| July - September | 2021

IR spectrometer with $\mathrm{KBr}$ pellets. ${ }^{1} \mathrm{H}$ NMR spectra were recorded at $400 \mathrm{MHz}$ on BRUKER AMX spectrophotometer using $\mathrm{CDCl}_{3}$ and TMS as internal standard. ${ }^{13} \mathrm{C}$ NMR spectra were recorded at $100 \mathrm{MHz}$ on BRUKER AMX $400 \mathrm{MHz}$ spectrometer using $\mathrm{CDCl}_{3}$ and the ${ }^{1} \mathrm{H}-{ }^{1} \mathrm{H} \mathrm{COSY},{ }^{1} \mathrm{H}-{ }^{13} \mathrm{C}$ COSY correlation spectra were recorded on BRUKER AMX $400 \mathrm{MHz}$ NMR spectrometer using standard parameters. Mass spectra were recorded with JEOL GCMATE II instrument. All the chromatographic purifications were performed with silica gel (100-200 mesh), whereas all TLC (Silica gel) was performed on silica gel coated (Merk Kiesel 60 GF-254, $0.2 \mathrm{~mm}$ thickness) sheets. All reagents and solvents are commercially obtained (Alfa asear, Himedia) and used directly without further purification.

\section{Synthesis of 3,3-dimethyl-2,6-diphenylpiperidin-4-ones, 1-4}

All the parent 3,3-dimethyl-2,6-diphenylpiperidin-4-ones were prepared by condensing ketone, aldehydes and ammonium acetate in warm ethanol in the ratio of 1:2:1, respectively, which afforded the formation of 3,3-dimethyl-2,6-diarylpiperidin-4-ones. ${ }^{11}$ The crude products formed were filtered and washed with an ethanol-ether (1:5) mixture to yield the compounds 1-4 and recrystallized from chloroform to obtain the pure compounds $\mathbf{1}-\mathbf{4}$.

\section{Synthesis of 3,3-dimethyl-2,6-diphenyl-4-(-2-(2,4,6-trichlorophenyl)hydrazono)piperidines, 6-9}

To the boiling solution of the 3,3-dimethyl-2,6-diphenyl piperidin-4-ones (25 mmol) (14), react with 2,4,6-trichlorophenyl hydrazine $(\mathbf{5})(25 \mathrm{mmol})$ in methanol and chloroform $(1: 1 \mathrm{v} / \mathrm{v})$, a few drops of acetic acid were added and refluxed for 2-4 $\mathrm{h}$. After completion of the reaction, the reaction mixture was cooled to room temperature. The precipitate was filtered and washed with petroleum ether. The crude product was recrystallized from ethanol. Newly target compounds (6-9) physical data are given in Table-1.

Table-1: Physical Data of Compounds 6-9

\begin{tabular}{c|c|c|c|c|c}
\hline Compounds & $\mathrm{R}_{1}$ & $\mathrm{R}_{2}$ & $\mathrm{X}$ & Melting Point $\left({ }^{\circ} \mathrm{C}\right)$ & Mass $(\mathrm{m} / z)$ \\
\hline 1,6 & $\mathrm{CH}_{3}$ & $\mathrm{CH}_{3}$ & $\mathrm{H}$ & $115-117$ & 471.32 \\
\hline 2,7 & $\mathrm{CH}_{3}$ & $\mathrm{CH}_{3}$ & $\mathrm{~F}$ & $130-132$ & - \\
\hline 3,8 & $\mathrm{CH}_{3}$ & $\mathrm{CH}_{3}$ & $\mathrm{Cl}$ & $125-127$ & - \\
\hline 4,9 & $\mathrm{CH}_{3}$ & $\mathrm{CH}_{3}$ & $\mathrm{Br}$ & $127-129$ & - \\
\hline
\end{tabular}

(E)-3,3-dimethyl-2,6-diphenyl-4-(-2-(2,4,6-trichlorophenyl)hydrazono)piperidine, 6 Yield: 70\%, White Solid: IR (KBr, $\mathrm{cm}^{-1)} ; v_{\max } 3340-3309(\mathrm{~N}-\mathrm{H} \mathrm{st}), 2816-3083(\mathrm{C}-\mathrm{Hst}), 1601(\mathrm{C}=\mathrm{N}$ st). ${ }^{1} \mathrm{H}$ NMR (400 MHz, CDCl $)$ ); $\delta$ (ppm) 1.06 (s, 3H, H-3e), 1.19 (s, 3H, H-3a), 1.67 (s, Moisture proton merged with NH), 2.39 (t, 1H, H-5a), 3.02 (dd, 1H, H-5e), 3.82 (s, 1H, H-2a), 3.96 (dd, 1H, H-6a), 7.04 (s, 1H, Hydrazine NH), 7.27-7.57 (m, 12H, aromatic protons). ${ }^{13} \mathrm{C} \mathrm{NMR}\left(100 \mathrm{MHz}, \mathrm{CDCl}_{3}\right) ; \delta(\mathrm{ppm}) 43.3$ (C-3), 159.3 (C-4), 31.6 (C-5), 61.2 (C-6), 70.7 (C-2), 21.2, 22.6 (C-3 alkyl carbons), 125.9-144.0 (aromatic and ipso carbons).

(E)-2,6-bis(4-fluorophenyl)-3,3-dimethyl-4-(2-(2,4,6-trichlorophenyl)hydrazono)piperidine, 7 Yield: 75\%, White Solid: IR (KBr, cm ${ }^{-1)} ; v_{\max } 3337-3315(\mathrm{~N}-\mathrm{H}$ st), 2818-3084 (C-H st), $1601(\mathrm{C}=\mathrm{N} \mathrm{st})$. ${ }^{1} \mathrm{H}$ NMR $\left(400 \mathrm{MHz}, \mathrm{CDCl}_{3}\right) ; \delta(\mathrm{ppm}) 1.03(\mathrm{~s}, 3 \mathrm{H}, \mathrm{H}-3 \mathrm{e}), 1.16(\mathrm{~s}, 3 \mathrm{H}, \mathrm{H}-3 \mathrm{a}), 1.63$ (s, Moisture proton merged with NH ), 2.33 (dd, 1H, H-5a), 2.99 (dd, 1H, H-5e), 3.79 (s, 1H, H-2a), 3.93 (dd, 1H, H-6a), 6.98 (s, 1H, Hydrazine), 7.00-7.54 (m, 10H, aromatic protons). ${ }^{13} \mathrm{C} \mathrm{NMR}\left(100 \mathrm{MHz}, \mathrm{CDCl}_{3}\right) ; \delta(\mathrm{ppm}) 43.1$ (C3), 158.9 (C-4), 31.7 (C-5), 60.5 (C-6), 69.9 (C-2), 21.2, 22.5 (C-3 alkyl carbons), 114.4-163.6 (aromatic and ipso carbons).

(E)-2,6-bis(4-chlorophenyl)-3,3-dimethyl-4-(2-(2,4,6-trichlorophenyl)hydrazono)piperidine, 8 Yield: 74\%, White Solid: IR (KBr, cm ${ }^{-1)} ; v_{\max } 3335-3321(\mathrm{~N}-\mathrm{H} \mathrm{st}), 2810-3078(\mathrm{C}-\mathrm{H} \mathrm{st}), 1596(\mathrm{C}=\mathrm{N} \mathrm{st})$. ${ }^{1} \mathrm{H}$ NMR $\left(400 \mathrm{MHz}, \mathrm{CDCl}_{3}\right) ; \delta(\mathrm{ppm}) 1.03(\mathrm{~s}, 3 \mathrm{H}, \mathrm{H}-3 \mathrm{e}), 1.15(\mathrm{~s}, 3 \mathrm{H}, \mathrm{H}-3 \mathrm{a}), 1.65$ (s, Moisture proton merged with NH), 2.32 (t, 1H, H-5a), 2.99 (dd, 1H, H-5e), 3.79 (s, 1H, H-2a), 3.93 (dd, 1H, H-6a), 7.01 (s, 1H, Hydrazine), 7.28-7.73 (m, $10 \mathrm{H}$, aromatic protons); ${ }^{13} \mathrm{C} \mathrm{NMR}\left(100 \mathrm{MHz}, \mathrm{CDCl}_{3}\right) ; \delta(\mathrm{ppm}) 43.1$ (C3), 158.5 (C-4), 31.5 (C-5), 60.5 (C-6), 70.0 (C-2), 21.1, 22.5 (C-3 alkyl carbons), 126.0-142.1 (aromatic and ipso carbons). 
RASĀYAN $J$. Chem.

Vol. 14 | No. 3 |1659-1668| July - September | 2021

(E)-2,6-bis(4-bromophenyl)-3,3-dimethyl-4-(2-(2,4,6-trichlorophenyl)hydrazono)piperidine, 9

Yield: 74\%, White Solid: IR (KBr, $\mathrm{cm}^{-1)} ; v_{\max } 3330-3315(\mathrm{~N}-\mathrm{H}$ st), 2850-3078 (C-H st), $1589(\mathrm{C}=\mathrm{N}$ st). ${ }^{1} \mathrm{H}$ NMR $\left(400 \mathrm{MHz}, \mathrm{CDCl}_{3}\right) ; \delta(\mathrm{ppm}) 1.03(\mathrm{~s}, 3 \mathrm{H}, \mathrm{H}-3 \mathrm{e}), 1.14(\mathrm{~s}, 3 \mathrm{H}, \mathrm{H}-3 \mathrm{a}), 1.81(\mathrm{~s}, 1 \mathrm{H}, \mathrm{NH}), 2.31(\mathrm{t}$, 1H, H-5a), 2.98 (dd, 1H, H-5e), 3.77 (s, 1H, H-2a), 3.91 (dd, 1H, H-6a), 7.00 (s, 1H, Hydrazine) 7.29$7.52\left(\mathrm{~m}, 10 \mathrm{H}\right.$, aromatic protons). ${ }^{13} \mathrm{C}$ NMR $\left(100 \mathrm{MHz}, \mathrm{CDCl}_{3}\right) ; \delta(\mathrm{ppm}) 43.0(\mathrm{C}-3), 158.4(\mathrm{C}-4), 31.5(\mathrm{C}-$ 5), 60.5 (C-6), 70.0 (C-2), 21.1, 22.5 (C-3 alkyl carbons), 121.5-142.7 (aromatic and ipso carbons).

\section{Determination of Minimum Inhibitory Concentration (MIC)}

The In-vitro antimicrobial activities of the compounds were tested in the dilution susceptibility testing method and the MIC determinations are reproduced concerning the cited literature ${ }^{24}$. The test compounds were dissolved in $1 \mathrm{~mL}$ of chloroform. The different concentrations of the test compounds were prepared with $200-3.125 \mu \mathrm{g} / \mathrm{mL}$. It was then serially diluted into two folds. Where $100 \mu \mathrm{L}$ of sterile Mueller Hinton Broth for bacteria and Sabouraud Dextrose broth for fungus was decanted into each well of a sterile 96well microplate. The highest concentration of the test compounds was added at $100 \mu \mathrm{L}$ to the first well. After mixing the above $100 \mu \mathrm{L}$ of the same was transferred to the second well and in this way, the dilution procedure was continued as a series of dilutions of 200-3.125 $\mu \mathrm{g} / \mathrm{mL}$, respectively. The final inoculums size was $10^{5} \mathrm{cfu} / \mathrm{mL}$ and antibacterial $1.1-1.5 \times 10^{2} \mathrm{cfu} / \mathrm{mL}$ for antifungal assay at $50 \mu \mathrm{L}$ was added to every well. They were being incubated $24 \mathrm{~h}$ at $37^{\circ} \mathrm{C}$ bacteria and yeast $36 \mathrm{~h}$ for Aspergillus of incubation. The tubes were monitored for turbidity growth and non turbidity as no growth. The MIC values were interpreted as the highest dilution (lowest concentration) of the sample, which showed clear fluid with no development of turbidity. Ciprofloxacin and Ketoconazole were used as standards for bacterial and fungal study, respectively.

\section{RESULTS AND DISCUSSION}

Spectral Analysis of Compounds, 6-9

IR Spectra

IR spectrum of the representative compound 9 is 3,3-dimethyl-2,6-diphenypiperidine showed that the carbonyl $\mathrm{C}=\mathrm{O}$ stretching frequency appeared around at $1720 \mathrm{~cm}^{-1}$. The presence of $\mathrm{C}=\mathrm{N}$ stretching frequency observed at $1589 \mathrm{~cm}^{-1}$ confirm the formation of hydrazones. However, the absence of carbonyl stretching frequency around $1720 \mathrm{~cm}^{-1}$ has also confirmed the formation of the target compound.

A collection of bands observed in the region $3330-3315 \mathrm{~cm}^{-1}$ is due to the $\mathrm{NH}$ stretching frequency. IR spectrum absorption arose from the aromatic and aliphatic $\mathrm{C}-\mathrm{H}$ stretching frequencies in the general region 3075-2775 $\mathrm{cm}^{-1}$. In compound 9 the absorption bands observed in the region $3078-2850 \mathrm{~cm}^{-1}$ are due to the aromatic and aliphatic $\mathrm{C}-\mathrm{H}$ stretching frequencies.

\section{${ }^{1}$ H NMR Spectral Analysis of Compound 9}

The ${ }^{1} \mathrm{H}$ NMR signals are assigned based on their position, multiplicity and integral values. In general, the aromatic protons resonated in the downfield region around at $7 \mathrm{ppm}$ due to the magnetic anisotropic effect. Spectral and conformation analysis of the compounds were made by comparison with (E)-2,6-bis(4bromophenyl)-3,3-dimethyl-4-(2-(2,4,6-trichlorophenyl)hydrazono)piperidine of 9 is shown in Fig.-1.

In ${ }^{1} \mathrm{H}$ NMR spectrum of 9 the signals appeared in the range of 7.29-7.52 ppm corresponding to ten protons integral values are assigned to the aromatic protons of the phenyl groups at C-2, C-6 and also to the phenyl protons of the 2,4,6-trichlorophenyl hydrazine moiety. The doublet of doublet appeared in the higher frequency region at $3.91 \mathrm{ppm}$ with a vicinal coupling constant value of $J_{5 \mathrm{a}, 6 \mathrm{a}}=12 \& J_{5 \mathrm{e}, 6 \mathrm{a}}=3.2 \mathrm{~Hz}$ is assigned to H-6a proton of piperidine ring system. The sharp singlet observed at $3.77 \mathrm{ppm}$ with one proton integral value is assigned for $\mathrm{H}-2 \mathrm{a}$ proton. Therefore, deshielded signal at $3.91 \mathrm{ppm}$ and the shielded signal at $3.77 \mathrm{ppm}$ are assigned to benzylic protons of $\mathrm{H}-6 \mathrm{a}$ and $\mathrm{H}-2 \mathrm{a}$. However, shielding of benzylic proton at C-2 is attributed to the substituent effect ( $+\mathrm{I}$ effect) of alkyl groups present at C-3 position.

A doublet of doublet appeared at $2.98 \mathrm{ppm}\left({ }^{3} J_{6 \mathrm{a}, 5 \mathrm{e}}=14 \& \&^{2} J_{5 \mathrm{a}, 5 \mathrm{e}}=3.2\right)$ corresponding to one proton integral value is assigned for $\mathrm{H}-5 \mathrm{e}$ proton. Consequently the $\mathrm{H}-5 \mathrm{a}$ proton appeared as triplet with one proton integral at $2.31 \mathrm{ppm}\left({ }^{3} J_{6 \mathrm{a}, 5 \mathrm{a}}=14 \&{ }^{2} J_{5 \mathrm{a}, 5 \mathrm{e}}=12.4\right)$. For the synthesized compounds (6-9), the chemical shift value of $\mathrm{H}-5 \mathrm{e}$ is greater than of $\mathrm{H}-5 \mathrm{a}$ proton. Also, $\mathrm{C}-5$ is a lower chemical shift than C-3. These observations suggested that the configuration about $\mathrm{C}(4)=\mathrm{N}$ bond is $E$. In such a configuration, the $\mathrm{C}(5)-\mathrm{H} 5 \mathrm{e}$ bond is 


\section{RASĀYAN J. Chem.}

Vol. 14 | No. 3 |1659-1668| July - September | 2021

polarized. Hence, H-5e gets a partial positive charge and C-5 acquires a partial negative charge. The positive charge on $\mathrm{H}-5 \mathrm{e}$ deshields and the partial negative charge on $\mathrm{C}-5$ shields it and $\mathrm{H}-5 \mathrm{a}$. However, shielding of syn $\alpha$-carbon is more pronounced than that of anti $\alpha$-carbon. This is due to the interaction of the H-5e proton and the proton of nitrogen bearing 2,4,6-trichlorophenyl hydrazine moiety. From this statement, the higher frequency signal at $2.98 \mathrm{ppm}$ is assigned to $\mathrm{H}-5 \mathrm{e}$ proton.<smiles>[X]c1ccc(C=O)cc1</smiles><smiles>[X]c1ccc(C2CC(=O)C([R])([R])C(c3ccc([X])cc3)N2)cc1</smiles><smiles>NNc1c(Cl)cc(Cl)cc1Cl</smiles>

5<smiles>[X]c1ccc(C2CC(=NNc3c(Cl)cc(Cl)cc3Cl)C(C)(C)C(c3ccc([X])cc3)N2)cc1</smiles>

6-9

Scheme-1

The signal that appeared at $1.03 \mathrm{ppm}$ is assigned to the methyl protons of the C-3 carbon in the equatorial position. Besides, another signal that appeared at $1.14 \mathrm{ppm}$ is assigned to C-3 axial methyl protons, which may be characteristic for equatorial and axial protons of the C-3 carbon. A sharp singlet with one proton integral value at $7.00 \mathrm{ppm}$ is assigned to $\mathrm{NH}$ proton of the 2,4,6-trichlorophenyl hydrazine moiety. Similarly, broad singlet appeared in the upfield region around at $1.81 \mathrm{ppm}$ with one proton integral value. This may be assigned to $\mathrm{NH}$ proton of the piperidine ring system of 9 . 


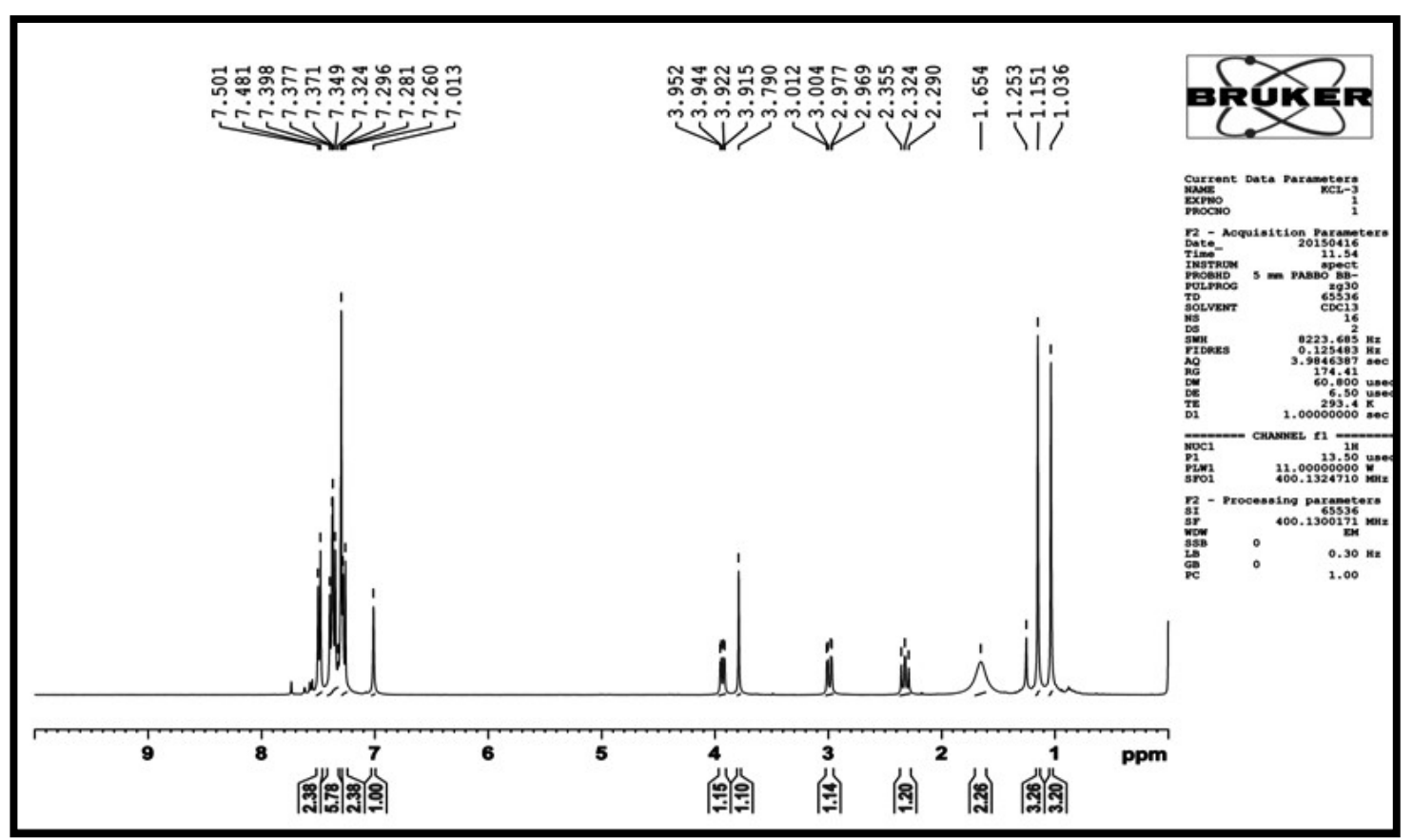

Fig.-1: ${ }^{1} \mathrm{H}$ NMR Spectrum of 9

\section{${ }^{1} \mathrm{H}-{ }^{1} \mathrm{H}$ COSY Spectrum of 9}

HOMOCOSY correlation data of compound9shows triplet at $2.31 \mathrm{ppm}$ shows the correlation with 2.98 and $3.91 \mathrm{ppm}$ suggesting that the signal appeared at 2.98 and $3.91 \mathrm{ppm}$ are due to H-5e and H-6a protons, respectively. Moreover, doublet of doublet observed at $2.98 \mathrm{ppm}(\mathrm{H}-5 \mathrm{e})$ shows a strong correlation with 2.31 and $3.91 \mathrm{ppm}$; hence the peaks are assigned to H-5a and H-6a protons. Similarly, a doublet of a doublet at $3.91 \mathrm{ppm}$ exhibitsa strong correlation with 2.31 (H-5a) and $2.98 \mathrm{ppm}(\mathrm{H}-5 \mathrm{e})$, confirming that the signal at $3.91 \mathrm{ppm}$ is designated to $\mathrm{H}-6 \mathrm{a}$ benzylic proton. ${ }^{1} \mathrm{H}-{ }^{1} \mathrm{H}$ COSY correlations of C-3 methyl protons are not observed due to the absence of adjacent protons.

\section{${ }^{13}$ C NMR Spectral Analysis of 9}

Generally, the signals due to the aromatic carbons can be very readily distinguished from that of other carbons. Similarly, the aromatic ipso carbons showed their resonances at a further downfield region compared to other aromatic carbons. Therefore, in all the compounds (6-9) the aromatic and ipso carbons can be identified by their characteristic absorption in the region of around 114.4-163.6 ppm.

The ${ }^{13} \mathrm{C}$ NMR spectrum of the representative compound 9 the carbon resonances at $121.5-142.7 \mathrm{ppm}$ are assigned to aromatic carbons and aromatic ipso carbons. The low intense signals observed at $158.4 \mathrm{ppm}$ are assigned to the $\mathrm{C}=\mathrm{N}$ carbon atom of the piperidine ring system. Further two low intense signals at 142.7 and $139.3 \mathrm{ppm}$ are due to ipso carbons of the phenyl rings at C-2' and C-6' carbon atom. There are four high-frequency signals observed in the aliphatic region. The signals observed at 70.0 and $60.5 \mathrm{ppm}$ are assigned to C-2 and C-6 carbons. Similarly, the signals that appeared at 43.0 and $31.5 \mathrm{ppm}$ are assigned to C-3 and C-5 carbons of the piperidine ring system. The alkyl substituted carbons at C-3 axial and equatorial positions of the methyl carbons are appeared at 21.1 and $22.5 \mathrm{ppm}$, respectively.

\section{${ }^{1} \mathrm{H}-{ }^{13} \mathrm{C}$ COSY Spectrum of 9}

The HSQC spectrum of compound $\mathbf{9}$ is shown in HSQC spectrum; the individual assignment for the methylene carbon C-5 and benzylic carbons C-2 and C-6 can be assigned unambiguously.

The individual assignment for the benzylic carbons C-2 and C-6 is done by the cross-peaks observed from their corresponding benzylic protons $\mathrm{H}-2 \mathrm{a}$ and $\mathrm{H}-6 \mathrm{a}$. The correlations of benzylic protons observed at 3.77 (H-2a) with $70.0 \mathrm{ppm}$ and 3.91 (H-6a) with $60.5 \mathrm{ppm}$ confirmed the C-2 and C-6 benzylic carbons. Further triplet and doublet of doublet observed at $2.31 \mathrm{ppm}(\mathrm{H}-5 \mathrm{a})$ and $2.98(\mathrm{H}-5 \mathrm{e})$ shows the cross peak with $31.5 \mathrm{ppm}$, confirming that the carbon resonance at $31.5 \mathrm{ppm}$ is due to the C-5 carbon. C- 3 methyl 
carbons resonated at 21.1 and 22.5 ppm showed a cross peak with the signal at 1.14 (axial methyl protons) and 1.03 (equatorial methyl protons) confirmed the C-3 methyl groups.

\section{Molecular Docking}

Docking studies were carried out to evaluate the binding affinity and the interactions between the synthesized compounds 6-9 and Human Lanosterol 14-demethylase (PDB Code: 3LD6). The docking score of the synthesized compounds 6-9 varies from -10.1 to -10.7 . The docking results indicate that the water molecules were present in the active site of CYP51 protein play an important role in binding. All the tested compounds display interactions with one water molecule are shown in Fig.-2. Compounds 6-9 have good glide score and the compound $\mathbf{8}$ exhibited halogen bond interactions with active site THR 135 residue. The halogen bond interaction with one water molecule were performed in the 2,4,6-trichloropheneyl hydrazine attached 2 nd and 4 th positions of chlorine atoms. This is essential for the inhibitory activity of CYP51 complex with ketoconazole protein (3LD6). The docking results clearly described that the tested compounds displayed various types of hydrophobic interactions with the amino acids present in the active site of CYP51 protein. The docking results are presented in Table-2.

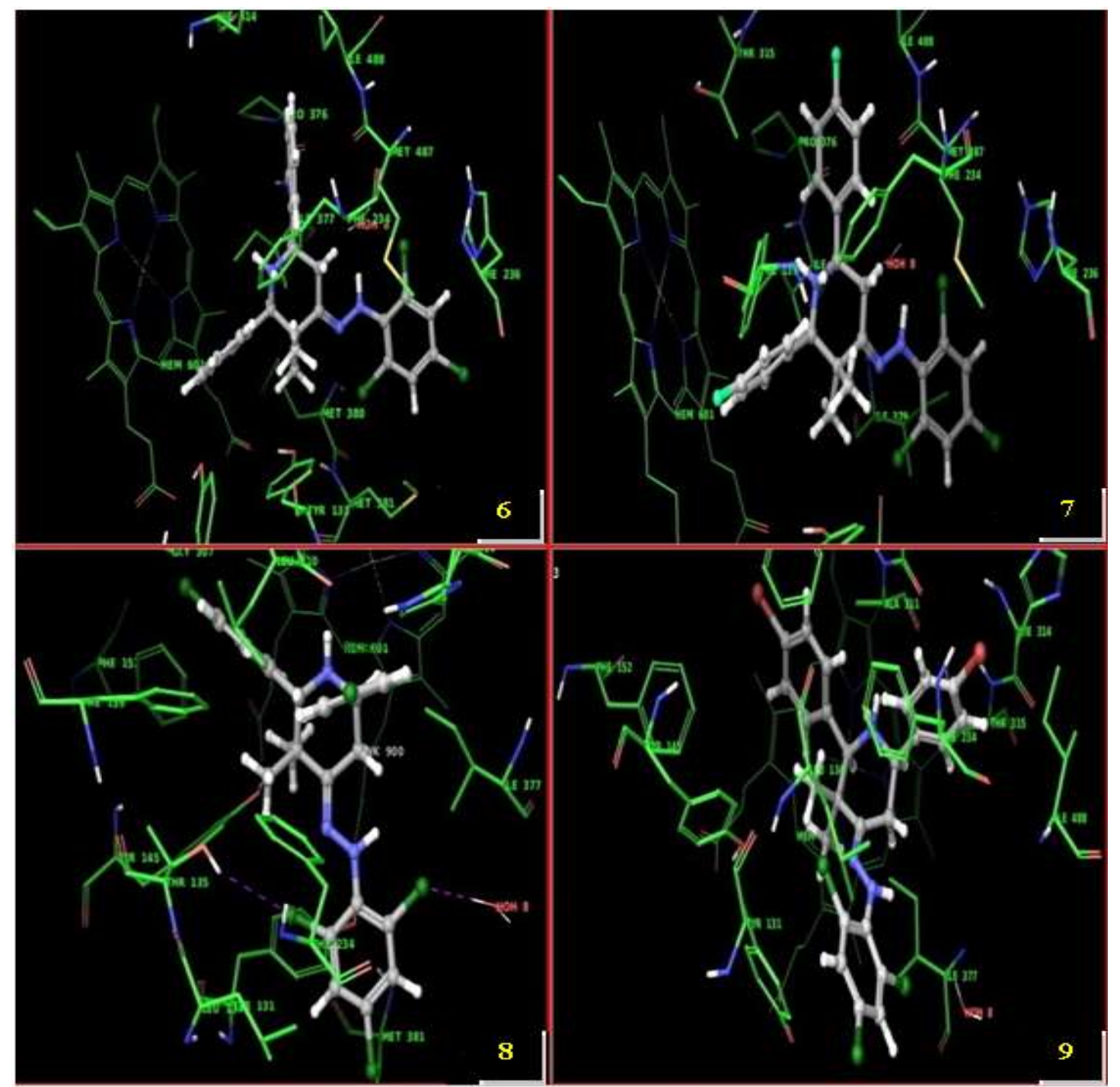

Fig.-2: 3D Interaction between 6- 9 and 3LD6 
RASĀYAN J. Chem.

Vol. 14 | No. 3 |1659-1668| July - September | 2021
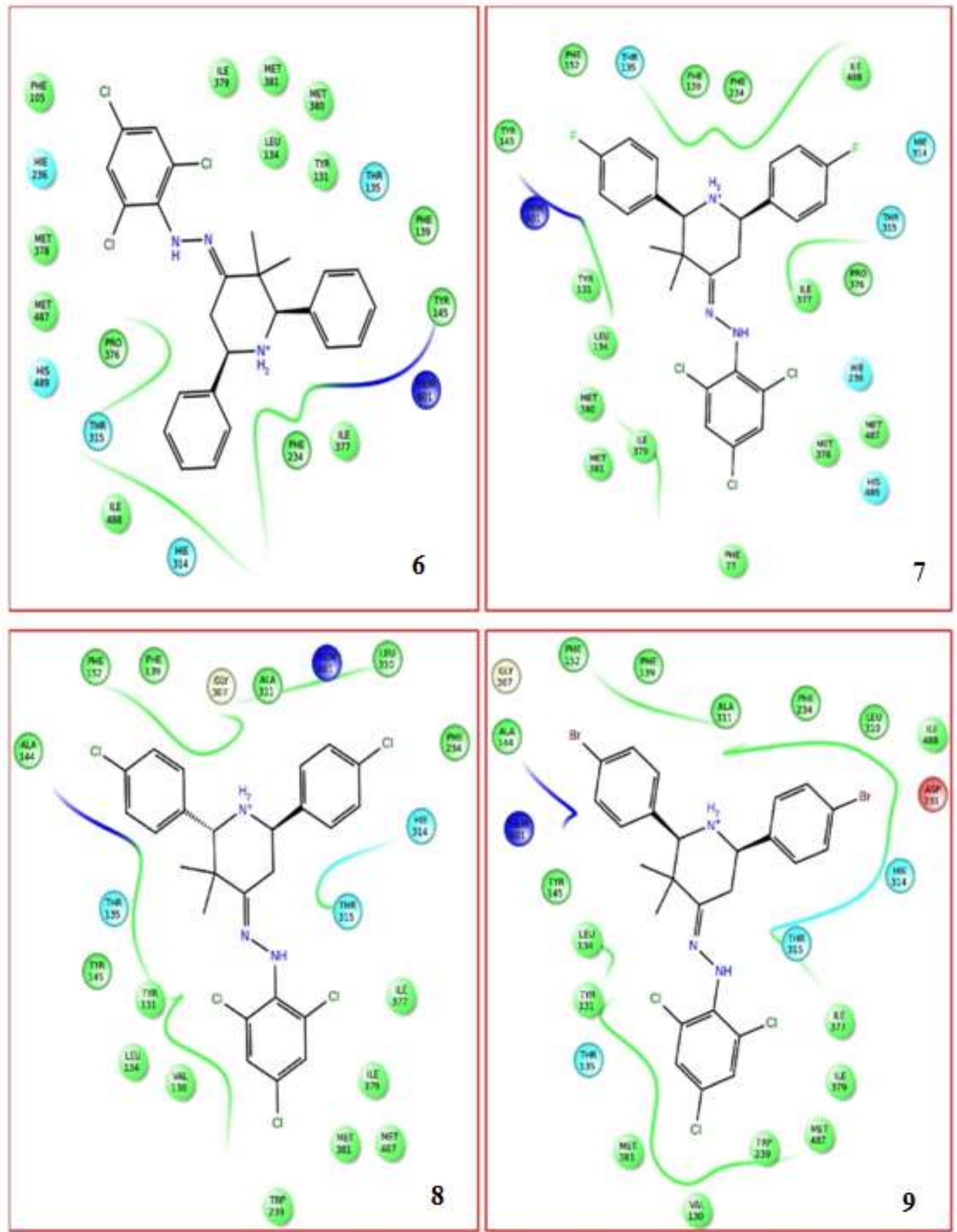

Fig.-3: 3D Interaction between 6- 9 and 3LD6

Table-2: Docking Results of the synthesized Compounds 6-9

\begin{tabular}{c|l|c}
\hline Compds. & \multicolumn{1}{|c}{ Hydrophobic Interacting Residues } & Gscore \\
\hline \multirow{2}{*}{6} & ILE-377,379,488; MET-378,380,381,487; & -10.1 \\
& PHE-105,139,234; LEU-134 & \\
\multirow{2}{*}{7} & PHE-77,139,152,234; TYR-131,145; & -10.4 \\
& LEU-134; MET-378,380,381; & \\
\hline \multirow{2}{*}{8} & ILE-377,379,488 & -10.7 \\
\hline
\end{tabular}


RASĀYAN J. Chem.

Vol. 14 | No. 3 |1659-1668| July - September | 2021

\begin{tabular}{l|l|c}
\hline & LEU-134,310 & \\
\hline \multirow{3}{*}{9} & PHE-139,152,234; ALA-144,311; & \\
& LEU-134,310;ILE-377,379,488; & -10.6 \\
\hline
\end{tabular}

The 3D and 2D views of interactions between the compound (ligand) and CYP51 (PDB ID: 3LD6) are displayed Fig.-3. It showed clearly that the 3,3-dimethyl-2,6-diphenyl-4-(-2-(2,4,6-trichlorophenyl) hydrazono)piperidine moieties of 6-9 are poses deep inside the pocket. This result is collaborated by molecular docking studies with fungal CYP51 inhibition, which shows that this compound presents the pharmacophoric requisites for fungal CYP51 complex with ketoconazole (3LD6) protein.

\section{Antimicrobial Activity}

\section{In-vitroAntibacterial and Antifungal Studies}

MIC tests were carried out according to the method of Andrews using a microtitre plate (96 wells) dilution method. The test compounds dissolved in $1 \mathrm{~mL}$ DMSO was tested in the different concentrations of $100,50,25,12.5,6.25$ and $3.12 \mu \mathrm{g} / \mathrm{mL}$ (2-fold serial dilution) with SDB and MHB. The bacterial strains viz. Staphylococcus aureus, Bacillus subtilis, Escherichia coli, Klebsiella pneumoniae Pseudomonas aeruginosa and fungal strains viz.Candida albicans, Candida glabrata, Candida tropicalis, Aspergillus niger and Aspergillus flavus were used in this study.

\section{Antibacterial Activity of Compounds 6-9}

Synthesized compounds 6-9 were evaluated for their antibacterial activity against Gram positive strains viz., S. aureus, B. subtilis and $K$. pneumoniae and Gram negative strains $E$. coli, and $P$. aeruginosa their minimum inhibitory concentration values with Ciprofloxacin standard drug. All the MIC values obtained for compounds 6-9 are given in Table-2.

Table-2: In vitroAntibacterial and Antifungal Activities of 6-9

\begin{tabular}{|c|c|c|c|c|c|c|c|c|c|c|c|}
\hline \multirow[b]{3}{*}{ Compds. } & \multirow{3}{*}{$\begin{array}{c}\text { Entry } \\
\mathrm{R}\end{array}$} & \multicolumn{10}{|c|}{ Minimum Inhibitory Concentrations $(\mu \mathrm{g} / \mathrm{mL})$} \\
\hline & & \multicolumn{5}{|c|}{ Antibacterial } & \multicolumn{5}{|c|}{ Antifungal } \\
\hline & & 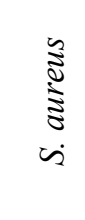 & 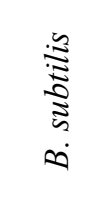 & $\begin{array}{l}\dot{\tilde{0}} \\
\dot{0}\end{array}$ & 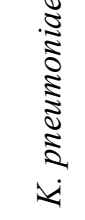 & $\begin{array}{l}0 \\
0 \\
0 \\
5 \\
0 \\
0 \\
0 \\
0 \\
0\end{array}$ & 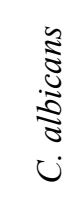 & 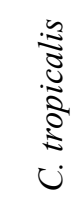 & $\begin{array}{l}5 \\
0 \\
0 \\
0 \\
0 \\
0\end{array}$ & 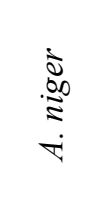 & $\frac{3}{3}$ \\
\hline 6 & $\mathrm{H}$ & 3.12 & 3.12 & 6.25 & 6.25 & 6.25 & 6.25 & 12.5 & 12.5 & 6.25 & 6.25 \\
\hline 7 & $\mathrm{~F}$ & 3.12 & 3.12 & 6.25 & 6.25 & 6.25 & 6.25 & 12.5 & 12.5 & 6.25 & 6.25 \\
\hline 8 & $\mathrm{Cl}$ & 3.12 & 3.12 & 6.25 & 6.25 & 6.25 & 6.25 & 12.5 & 12.5 & 6.25 & 6.25 \\
\hline 9 & $\mathrm{Br}$ & 3.12 & 3.12 & 6.25 & 6.25 & 6.25 & 6.25 & 12.5 & 12.5 & 6.25 & 6.25 \\
\hline \multirow{2}{*}{\multicolumn{2}{|c|}{ Ciprofloxacin }} & 6.25 & 6.25 & 12.5 & 12.5 & 12.5 & - & - & - & - & - \\
\hline & & - & - & - & - & - & 12.5 & 25 & 12.5 & 12.5 & 12.5 \\
\hline
\end{tabular}

Unsubstituted compound 6 was found to be excellent antibacterial character against $S$. aureus and B. subtilis even at a low concentration of $3.125 \mu \mathrm{g} / \mathrm{mL}$. However, compound 6 exhibited superior activity against E. coli, K. pneumoniae and P. aeruginosa at a MIC value of $6.25 \mu \mathrm{g} / \mathrm{mL}$. Compounds 7-9 containing para fluoro, chloro and bromo phenyl substituent at C-2 and C-6 in the monocyclic piperidine ring showed the outstanding antibacterial activities against $S$. aureus and B. subtilis with a MIC value of 3.125 $\mu \mathrm{g} / \mathrm{mL}$. In addition, compounds 7-9 exhibited two fold increased antibacterial activities against $E$. coli, $K$. pneumoniae and $P$. aeruginosa compared with the standard drug.

\section{Antifungal Activity of Compounds 6-9}

The newly synthesized compounds 6-9 were assessed for their in vitro antifungal activity against a panel of fungal strains. Compounds 6-9 against $C$. albicans, C. tropicalis, A. nigerand A. flavus showedtwo fold increased antifungal activity than the reference drug. However compounds 6-9 exhibited better antifungal activitiy against $C$. glabrata with the MIC value of $12.5 \mu \mathrm{g} / \mathrm{mL}$. The results of the study demonstrated 
RASĀYAN J. Chem.

Vol. 14 | No. 3 |1659-1668| July - September | 2021

that electron withdrawing groups at the para position of the aromatic ring in the piperidine moiety and 2,4,6-trichlorophenyl hydrazine scaffold exerted higher inhibitory effect against various tested microbes. In addition, the antifungal activities got increased due to the presence of more halogen atoms in the target molecules. The minimum inhibitory concentration (MIC in $\mu \mathrm{g} / \mathrm{mL}$ ) of the compounds 6-9 against the tested bacterial and fungal strains result are given in Table-2.

Molecular docking studies have also indicated that the synthesized compounds 6-9 possessed appreciable binding energy values against 3LD6 protein. It is more attractive to speculate that the result of the antimicrobial activities varied with the nature of substituents on the 2,4,6-trichlorophenyl hydrazine at C-4 position.
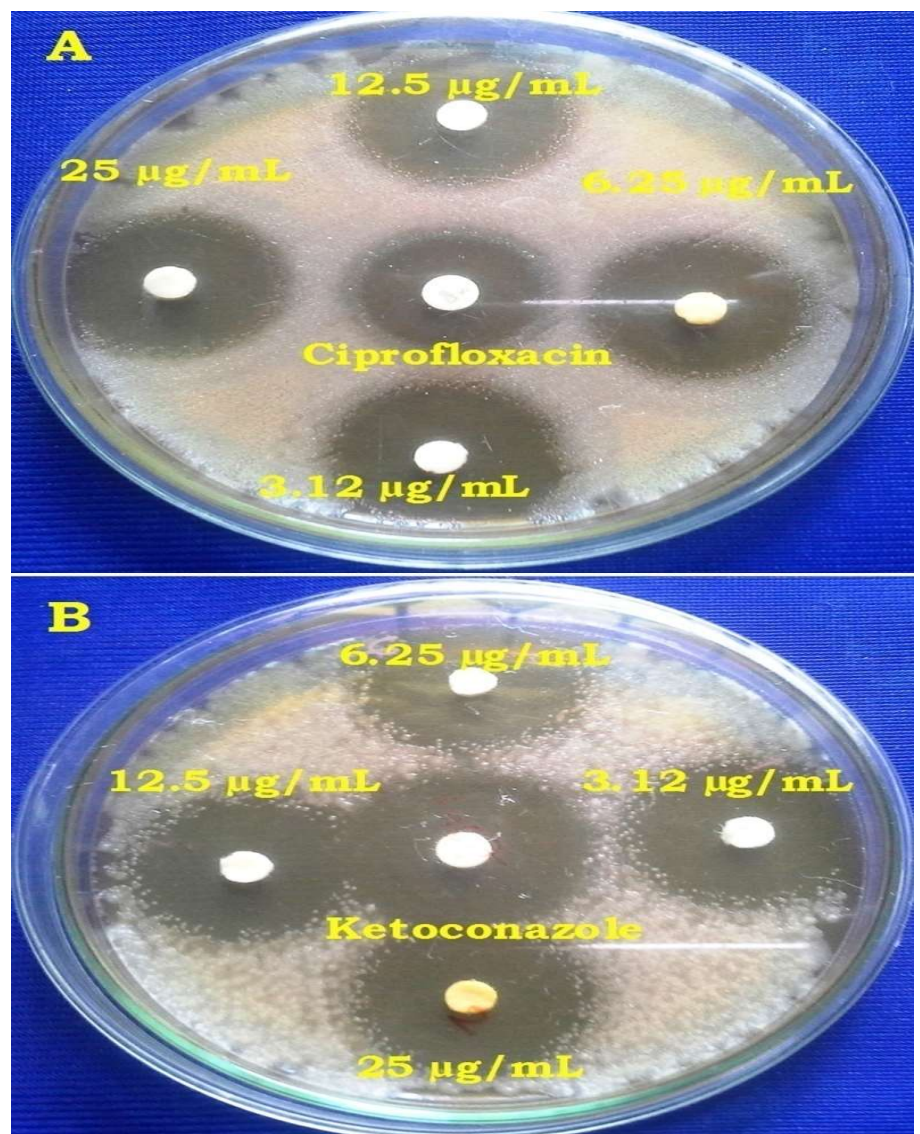

Fig.-3: The Corresponding Zone of Inhibition of 9 against (A) S. aureus and (B) C. albicans

\section{CONCLUSION}

3,3-dimethyl-2,6-diphenyl-4-(-2-(2,4,6-trichlorophenyl)hydrazono)piperidine were synthesized and screened for antimicrobial activity. Compounds 6-9 exhibited excellent antimicrobial activity. The docking studies of synthesized compounds 6-9 with lanosterol 14 $\alpha$-demethylase (CYP51) modeled protein showed good binding interactions and formed various hydrophobic interactions with active site residues. The results of in vitro antifungal activity and molecular docking study revealed that the synthesized compounds 6-9 have potential antifungal activities and can be further optimized and developed as a lead compound. The acquired structure-activity relationships showed that suitably substituted 3,3-dimethyl-2,6diphenyl-4-(-2(2,4,6 trichlorophenyl)hydrazono)piperidine have the necessary geometry to Provide potent and selective inhibition of the fungal CYP51 protein (PDB ID:3LD6).

\section{ACKNOWLEDGEMENT}

The authors K. Krishnasamy and D. Rajaraman thank the university grant commission for the financial support (Major Research Project, F. NO: 42-342/2013). The authors extended thank to the Department of Botany, Annamalai University, for carrying out the antimicrobial activities. 
RASĀYAN J. Chem.

Vol. 14 | No. 3 |1659-1668| July - September | 2021

\section{REFERENCES}

1. M.G. Valverde, and T. Torroba, Molecules 10(2), 318 (2005), https://doi.org/10.3390/10020318

2. L.Savini, L.Chiasserini, V.Travagli, C.Pellerano, E.Novellino, S.Cosentino, and M. Barba Pisano, European Journal of Medicinal Chemistry, 39(2), 113 (2004), https://doi.org/10.1016/j.ejmech.2003.09.012

3. O.O. Ajani, C.A.Obafemi, O.C.Nwinyi, and D.A. Akinpelu, Bioorganic and Medicinal Chemistry, 18(1), 214 (2019), https://doi.org/10.1016/j.bmc.2009.10.064

4. S.Rollas, and S. Guniz Kucukguzel, Molecules, 12(8), 1910 (2007), https://doi.org/10.3390/12081910

5. R. Narang, B. Narasimhan, and S. Sharma, Current Medicinal Chemistry,19(4), 569 (2012), https://doi.org/10.2174/092986712798918789

6. W. Ahmed, M. Rani, I.A. Khan, A. Iqbal, K. M Khan, M A Haleem, and M K. Azim Journal of Enzyme Inhibition and Medicinal Chemistry, 25(5), 673 (2010), https://doi.org/10.3109/14756360903508430

7. H. Shirinzadeh, and E. Dilek, Journal of Molecular Structure, 1220, 128657, (2020), https://doi.org/10.1016/j.molstruc.2020.128657

8. H. Beraldo, Quimica Nova, 27,461 (2004), https://doi.org/10.1590/S0100-40422004000300017

9. K. Mohammed Khan, Z. Shah, V. Uddin Ahmad, M. Khan, M. Taha, F. Rahim, S. Ali, N. Ambreen, S. Perveen, M. Iqbal Choudhary, and W. Voelte, Medicinal. Chemistry, 8(3), 452(2012), https://doi.org/10.2174/1573406411208030452

10. G. L. Balaji, V. Vijayakumar and K. Rajesh, Arabian Journal of Chemistry, 9, S1101(2016), https://doi.org/10.1016/j.arabjc.2011.12.011

11. C.R. Noller, and V. Balliah, Journal of the American Chemical Society, 70(11), 3853(1948), https://doi.org/10.1021/ja01191a092

12. K. Pandiarajan, R.T.S. Mohan, and B. Krishnakumar, Indian Journal of Chemistry B, 26, 624 (1987).

13. M. Mubashar Idrees, Y.G. Bodkhe, N. J. Siddiqui, and Sezgin Kola, Rasayan Journal of Chemistry, 13(1), 291(2020), https://doi.org/10.31788/RJC.2020.1315593

14. P. S. Watson, B. Jiang, and B. Scott, Organic Letter, 16:2(23), 3679 (2000), https://doi.org/10.1021/ol006589o

15. S. Ruben Vardanyan, and J. Victor Hruby, Future Medicinal Chemistry, 6(4), 385 (2014), https://doi.org/10.4155/fmc. 13.215

16. Geetha Birudala, G .Swarnalatha, and G. V. Subba Reddy Rasayan Journal of Chemistry, 12(3), 1063(2019), https://doi.org/10.31788/RJC.2019.1235165

17. I. Collins, W.B. Davey, M. Rowley, K. Quirk, F.A. Bromidge, R.M. Mc Kernan, S. A. Thompson, and K. A. Wafford, Bioorganic \& Medicinal Chemistry Letters, 10, 1381(2000), https://doi.org/10.1016/s0960-894x(00)00245-6

18. G. P. Maxime, Buffat, Tetrahedron, 60, 1701 (2004), https://doi.org/10.1016/j.tet.2003.11.043

19. D. Kumaraswamy and V. Mallareddy, Rasayan Journal of Chemistry, 9(2), 169(2016).

20. W. Lijinsky, and H.W. Taylor, International Journal of Cancer,16, 318(1975), https://doi.org/10.1002/ijc.2910160215

21. H.I. El-Subbagh, S.M. Abu-Zaid, M.A. Mahran, F.A. Badria, and A.M. Al-Obaid Jurnal of Medicinal Chemistry, 43, 2915 (2000), https://doi.org/10.1021/jm000038m

22. A. A. Watson, G.W.J. Fleet, N. Asano, R.J. Molyneux, and J. Nash, Phytochemistry, 56, 265 (2001), https://doi.org/10.1016/s0031-9422(00)00451-9

23. K. Niknam, A. Deris, F. Naeimi, and F. Majleci, Tetrahedron Letter, 52, $4642(2011)$, https://doi.org/10.1016/j.tetlet.2011.06.105

24. J. M. Andrews, Journal of Antimicrobial Chemotherapy, 48, 5(2001), https://doi.org/10.1093/jac/48.suppl-1.5

[RJC-6428/2021] 